\title{
INCREASING THE INTRODUCTION OF BALANCED NUTRITIOUS FOOD THROUGH COOKING CLASS ACTIVITY ON CHILDREN OF 3-4 YEARS OLD AT PPT PELANGI KECAMATAN PAKAL SURABAYA
}

\author{
Abdul Muhith ${ }^{1}$, Pance Mariati ${ }^{2}$, hartadi ${ }^{3}$. Maya Zainiyah ${ }^{4}$ \\ ${ }^{1}$ Nursing science Department-University of Nahdlatul Ulama Surabaya Indonesia (UNUSA) \\ ${ }^{2,}{ }^{4}$ Faculty Teachership and Education Science-University of Nahdlatul Ulama Surabaya \\ Indonesia (UNUSA) \\ ${ }^{3}$ Nursing Science Department-STIKes Bina Sehat PPNI Mojokerto Indonesia \\ Email : abdulmuhith@unusa.ac.id, Pance_mariati@unusa.ac.id, hartadinkeskabmojokerto@gmail.com, \\ maya.tk15@student.unusa.ac.id
}

\section{ABSTRACT}

The research purpose is to increase the introduction of balanced nutritions food. The research method used was Classroom Action Research (CAR). The research subjects were 22 children of 3-4 year old children at PPT Pelangi, Pakal, Surabaya. Data collection techniques included : planning, implementation, observation and reflection. This research consisted of pre-cycle, cycle I and cycle II with 2 meetings/ cycle. The research result showed that in the pre-cycle, it obtained 46,6\%, there was An increase in the first cycle of $61,4 \%$, it showed an increase in the number of children who developed well, although it was not maximally yet, in the second cycle, It increased as $83 \%$ it showed an increase in the percentage of development with very good growth.

\section{Keywords}

Balanced

Nutritionof

Children,

CookingClass

\section{INTRODUCTION}

The Improvement of the quality of education must be supported with health condition and fulfilled nutrient. Main factor that influences the status of child nutrition is the sufficiency of the food consumption (Almatsier, 2001). Food is really important to support the viability and the child growth outcomes. Children tend to buy foods sold near school (Aulina .M.Kes, 2011). Thing that needs to be paid attention to is several health issues regarding the safety of the foods. Foods we often meet are not supposed to be consumed by children in their age (Damayanti, 2011), (Damayanti, 2013).

Permendiknas No.58 in 2009 in laws Nomor 20 in 2003 about the national education system article 1 no. 14 states: "Early Childhood Education (PAUD) is an effort of development on children since birth to 6 years old that is done through giving education stimulus to help the growth and development of both physical and spiritualso that the children are ready to enter further education" (Kurikulum Pendidikan Anak Usia Dini, 2013). 
Introducing nutritious foods to early childhood is really important so that that they have enough knowledge what nutritious food is and its benefit for their body. The role of Early Childhood Education (PAUD) is to be able to help and create the quality of the children in the future. Based on the researcher's observation done at PPT Pelangi, Pakal Surabaya, in fact, researcher found foods that are consumed by children of 3-4 years old still don't contain balanced nutrient. It can be seen from foods that are consumed by childrennear school area. From 22 children, 15 of them don't show appropriate development as it should be in that age. This is showed on Children Growth Card from Posyandu (Kurniawaty, Lia. 2017).

One of the ways to increase the introduction of balanced nutritious foods done by researcher is using activity of cooking class. The learning process of the introduction of foods can give important role for their knowledge and eating habits of children. Teachers used to introduce nutritious food through uninteresting pictures to children (Purnamasari, 2018).

The aim of this research is to increase the introduction of balanced nutritious foods through activity of cooking class. With this research, children are expected to be able to increase their knowledge about balanced nutritious foods and Cooking Class is one of the learning processes to help children increasing their knowledge about balanced nutritious foods designed in activity situation by uniting method and technique of interesting learning (Santoso, 2004).

\section{METHOD}

This research is done at PPT Pelangi, Pakal,Surabaya. The research subjects of the research were a group consist of 22 children of 3-4 years old, done in the end of semester II the academic year 2018/2019. The research used Classroom Action Research (CAR). The reason why researcher chose this kind of research is so that this research can be done in class, problems experienced by teacher from the result of the research can be used by teacher and experience it directly in class, there is repeated upgrading (Arikunto, 2010).

This research is an effort to fix the learning process condition with the hope that there will be no more problems in class. Demonstration method is an effective method because it can help the students see directly the process of certain thing happen. The procedure of this research hasfour steps such as: planning, implementation, observation and reflection on each cycle. Every cycle has two meetings in the learning process. The source of data obtained from the observation in the school and complains from teachers through learning activity. Data used in this research includes observation paper and documentation.

Researcher is an observer who is helped by teacher by using observation paper. Data that is obtained is observation data from observation process for each cycle. The instrument for this research consists of indicators in introducing clean, healthy and nutritious foods and beverages.

This research is quantitative and qualitative research. Data that is obtained quantitatively is then analysed with descriptive analysis. Qualitative data explains the student's activity that can be obtained from observation paper. The formula used is (Arikunto, 2010:21):

$$
\mathrm{P}=\frac{f}{n} \times 100 \%
$$

The indicator of success in this research is if minimum $80 \%$ of the total of student reach the criteria BSB (Berkembang 
Sangat Baik/ Growing So Well) that is already determined by researcher. The number of success of $80 \%$ is obtained from children who get score 3 and score.

\section{RESULTS}

This research is done to introduce balanced nutritious foods through cooking class activity on children of 3-4 years old in PPT Pelangi, Pakal, Surabaya. The research result consisted of pre-cycle, cycle I, and cycle II. Before conducting Classroom Action, researcher had done observation about this research in advance for about one month to know how good the children's knowledge about clean, healthy and nutritious foods and beverages.

In the research of cycle II, there is an increase that excels the indicator of success. It is caused by the educative game tool added by researcher and teacher to make children know the real shape and color. Based on the calculation, it can be concluded that cycle II has been fulfilled so there will be no more further action taken and the research stopped at cycle II. The result of reflection can be obtained that there is escalation of the introduction of balanced nutritious food to children of 3-4 years old in the group B in PPT Pelangi through cooking class activity. The increase on pre-cycle II is $46,6 \%$, the increase on cycle $\mathrm{I}$ is $61,40 \%$ and the increase of cycle II is $83 \%$.It showed an increase in the percentage of development with very good growth.Here are the recapitulation of the result of pre-cycle, cycle I and cycle II:

The Table 1. Recapitulation of Result obtained in the increase of introduction of balanced nutritious food

NoIndicator
Pre- Cycle cycle ycle I
1 Doing activity that show46,6 61,4 $83 \%$ children are able to $\%$ differentiate clean, healthy and nutritious food and beverage

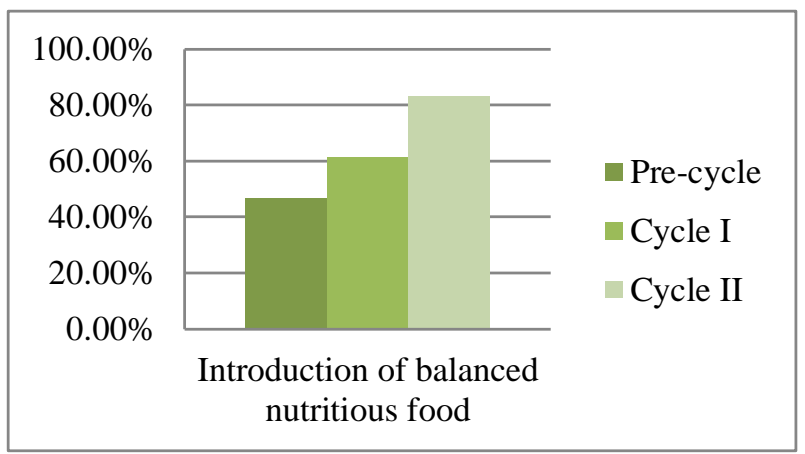

Picture 1. Chart of recapitulation of the whole increase of the introduction of balanced nutritious food

\section{DISCUSSION}

In order to increase the optimal growth of children researcher is interested to hold an observation in one institute of Early Childhood Education located in Babat Jerawat, Pakal Surabaya that is PPT Pelangi. Description of the school condition contains place of research, educational facilities, and the schedule of learning process. Vision and Mission that are have already become the aim of PPT Pelangi are showed from learning process with help of experienced and trained teachers to achieve the vision and mission (Wahyuni, 2014).

In planning process, with the help of teachers of PPT Pelangi in arranging the problem formulation that will be researched, designing the topic and sub topic of learning, preparing RPPH and RPPM by using curriculum 2013 about early childhood education, designing the schedule of learning, preparing instrument of scoring and also media used in activity, preparing 
place or classroom and tools that are going to be used (Suyadi, 2010).

In the implementation of beginning activity of pre-cycle includes welcoming children, singing, rough motoric, praying and calling the roll. In the main activity, as the topic that has been decided, children are asked to mention kinds of clean, healthy, and nutritious food and beverage. In the cooking class, children are asked to cook foods that contain substance of balanced nutrient. In this research, children try to arrange burger that has been prepared by researcher and teachers. Before doing the activity, teachers had explained the ingredients and tools used in the activity and children are asked to wear apron and chef's hat. From the result obtained, there are still many children who don't know yet about clean, healthy and nutritious food and beverage(Abdul Muhith, Yusak anshori Mohamad, 2019).

This thing happens due to the fear experienced by the children to do the activity that is still unfamiliar to them. The children never know kinds of food that contain carbohydrate and protein. It is also difficult for them to mention healthy fruits, vegetables and beverages. Yet they feel excited because theycan make their own food. Knowing the result of observation, teachers started and planned the next activity to increase their knowledge. Then, the cycle I was held with the note that teachers should be more excited and motivate the children to be more confident doing the activity fearlessly.

Based on the implementation of cycle I with the same process, researcher just added media in the learning process that is educative game tools such as fruits and vegetables. Out of 22 children, there are only several children who don't show improvement in the introduction of balanced nutritious food. The result of reflection showed that there are still some children who still don't know about balanced nutritious food.

There are several factor of the problem; children are still afraid doing mistake and become mocked by their friends, time management of the learning process of cycle I still needs to be improved because the time allocation that is already decided in RPP can't be implemented. Confidence of children also needs to be improved. Yet the children feel excited doing the learning process. After doing reflection, teacher prepared the activity of cycle II. With this, researcher continued to research of cycle II to reach the target of success level.

With the cooking vlass activity, children feel more excited to do the activity, they become more active to ask question and eat the food made by them. With the help of Active game tool, the become more motivated to be curious about other nutritious foods. Based on the analysis, also supported by Piaget's opinion in Suyadi (2010:79) that knowledge, introduction can be built through learning activity. So, the aim of this research has succeeded and the problem formulation has been solved. Besides, the hypothesis of action that has been done has been proven successful.

This research is analogous with the researched conducted by Lia Kurniawaty (2017) that the implementation of cooking class activity can increase children's knowledge from knowing nothing about the concept of healthy foods to be able to show, mention, explain and also doing something regarding with the healthy foods. Based on Damayanti (2013:15) by cooking together with children can accustom healthy eating habit to them and will be their habit until they grow up in the future. 
The habituation in setting eating habit is one of efforts to maintain the health of children; this is analogous with the research result of Bellock and Breslow in Santoso (2004:18). Combination pattern is needed between habituation of eating habit, nutrition, arrangement of portion on children and the sense of parents to see signs of malnutrition on children. Based on the analysis done by researcher, cooking class activity can increase the introduction of balanced nutritious foods and also can motivate children to eat clean, healthy and nutritious foods. Thereby, the aim of this research has been reached and the problem formulation has been solved. Besides, the hypothesis of action that has been done has proven successful

\section{CONCLUSIONS}

Classroom action, it can be concluded that cooking class activity can increase the introduction of balanced nutritious foods on children of 3-4 years old in PPT Pelangi, Pakal, Surabaya. Cooking Class activity can give new knowledge about number and amount, color, and train rough motorist and smooth motorist, introduce healthy food and beverage, and also the terms of kitchen tools that can improve children's cognitive, train children to live healthily and cleanly.

\section{REFERENCES}

Abdul Muhith, Yusak anshori Mohamad, P. S. (2019) 'Determinant Factors Affecting the Nutritional Status of Children in Regional Health Center of Gresik', Indian Journal of Public Health Research \& Development, 10(11), pp. 1738-1743. Available at:

http://www.indianjournals.com/ijor. aspx ?target=ijor:ijphrd \&volume $=1$ 0\&issue $=11 \&$ article $=394$.

Almatsier, S. (2001) Prinsip Dasar Ilmu Gizi. Jakarta. Gramedia Pustaka Utama.

Arikunto, S. (2010) Prosedur Penilaian Suatu Pendekatan Praktik. Jakarta: Rineka Cipta.

Aulina .M.Kes, R. (2011) Konsep Dasar Ilmu Gizi.

Damayanti, D. (2011) Masak Bersama Si Kecil Tips Kenalkan Aneka Jenis Makanan Plus 25 Resep Praktis. Jakarta: PT. Gramedia Pustaka Utama.

Damayanti, D. (2013) Makanan \& Kegiatan Sekolah Anak Tips Siapkan Makanan Untuk Kegiatan di Sekolah Plus 25 Resep Preaktis. Jakarta: PT. Gramedia Pustaka Utama.

Kurikulum Pendidikan Anak Usia Dini (2013). Jakarta.

Kurniawaty, Lia Peningkatan Pengetahuan Tentang Makanan Sehat Melalui Kegiatan Bermain Cooking Class Kebonsari Kota Cimahi. (2017).

Purnamasari, D. U. (2018) Panduan Gizi \& Kesehatan Anak Sekolah. Yogyakarta: Andi.

Santoso, S. L. A. R. (2004) Kesehatan dan Gizi. Jakarta: Rineka Cipta.

Suyadi (2010) Psikologi Belajar Pendidikan Anak Usia Dini. Yogyakarta: Pedagogia.

Wahyuni, T. (2014) Peningkatan Motivasi Anak Makan Sayuran Melalui Metode Bermain Permainan cooking class pada anak usia 5-6 tahun". 